\title{
Physiological studies on Marphysa gravelyi Southern V. Regulation of chlorides, sodium, potassium and total free amino acids ${ }^{1}$
}

\author{
Bhupalam Krishnamoorthi ${ }^{2}$ and S. Krishnaswamy \\ Department of Zoology, University of Madras, Madurai Centre, Madurai-2, S. India
}

\begin{abstract}
KURZFASSUNG: Physiologische Studien an Marphysa gravelyi Southern: V. Regulation von Chloriden, Natrium, Kalium und Gesamtmenge an freien Aminosäuren. Der brackwasserlebende Polychaet Marpbysa gravelyi vermag alle getesteten Ionen seines Innenmediums - Chloride, Natrium, Kalium - gegenüber den im Außenmedium vorhandenen Konzentrationen dieser Ionen zu regulieren. Die quantitativen Verhältnisse zwischen $\mathrm{Na}$ und $\mathrm{Cl}, \mathrm{K}$ und $\mathrm{Cl}$, $\mathrm{K}$ und $\mathrm{Na}$ sowie $z$ wischen $(\mathrm{Na}+\mathrm{Cl})$ und $(\mathrm{K}+\mathrm{Cl})$ werden dabei weitgehend konstant gehalten. Bei der Osmoregulation der Körperflüssigkeiten spielt offenbar auch eine intrazelluläre Regulation eine Rolle, bei welcher die Konzentration der Aminosäuren von Bedeutung ist.
\end{abstract}

\section{INTRODUCTION}

Evidences so far gathered have revealed that Marphysa gravelyi SOUTHERN, a eunicid brackish water polychaete, tolerates lowered salinities over a wider range (Krishnamoorthi \& Krishnaswamy 1965a) than its co-inhabitants (KrishnaMOORTHI 1962); its powers of volume control are far better developed, perhaps reflecting a reduction in permeability (KRISHNAMOORTHI \& KRISHNASWAMY 1965b); it is a hyporegulator maintaining the depression in the freezing point of its body fluid not only steadily over a wide range of external salinities but also keeping it at the minimum level so far known among polychaete species (KRISHNAMOORTHI \& KRISHNASWAMY 1965c); and the ratio of the excretory surface to the length of the worm is the highest (Krishnamoorthr \& Krishnaswamy 1965d) compared with ratios obtained in other polychaetes inhabiting similar regions (KRISHNAmoorTHI 1963a). Furthermore, the fact that anterior bits of $M$. gravelyi maintained a sustained activity over a wide range of dilute media (KRISHNAMOORTHI \& KRISHNASWAMY 1963), emphasized the need for a study of ionic regulation as well as the regulation of organic solutes in the body fluid, since there seems to be little doubt that osmotic regulation of body fluids in invertebrates is secondary to ionic regulation (PANTIN

1 This paper represents part of a thesis accepted for the award of the $\mathrm{Ph}$. D. degree of the University of Madras, to the senior author.

2 Present Address: Central Marine Fisheries Research Unit, WALTAIR, Visakhapatnam-3, A. P., India. 
1931). This has been demonstrated by a series of studies on crustaceans (ROBERTSON 1939, 1949, 1953, 1960a; WebB 1940; PARRy 1954; Shaw 1955a, b, 1960c; Bryan $1960 \mathrm{a}, \mathrm{b}, \mathrm{c})$. Isolated muscle preparations of Nereis diversicolor exhibited sustained activity in media as dilute as the least saline water (Wells \& Ledingham 1940) indicating, as pointed out by BEADLE (1957), doubtful survival values for its powers of osmotic regulation. That $\mathrm{Cl}, \mathrm{Na}$ and $\mathrm{K}$ are regulated by $M$. gravelyi has already been briefly reported (KRISHNAMOORTHI 1963c; Krishnamoorthi \& KRISHNASWAMY 1965f).

\section{MATERIAL AND METHODS}

The chlorides were estimated from $0.1 \mathrm{ml}$ of coelomic fluid made up to $1 \mathrm{ml}$ by the method of SENDroy (1937), as modified by Robertson \& WeBb (1939). The sodium and potassium were determined using a flame-photo-meter (Zeiss). Since preliminary estimations had shown that a minimum dilution of coelomic fluid up to 200 times was necessary to read it on the scale of the flame-photo-meter, all determinations were made from samples $(0.05 \mathrm{ml})$ diluted up to 200 times. Standard graphs from estimations

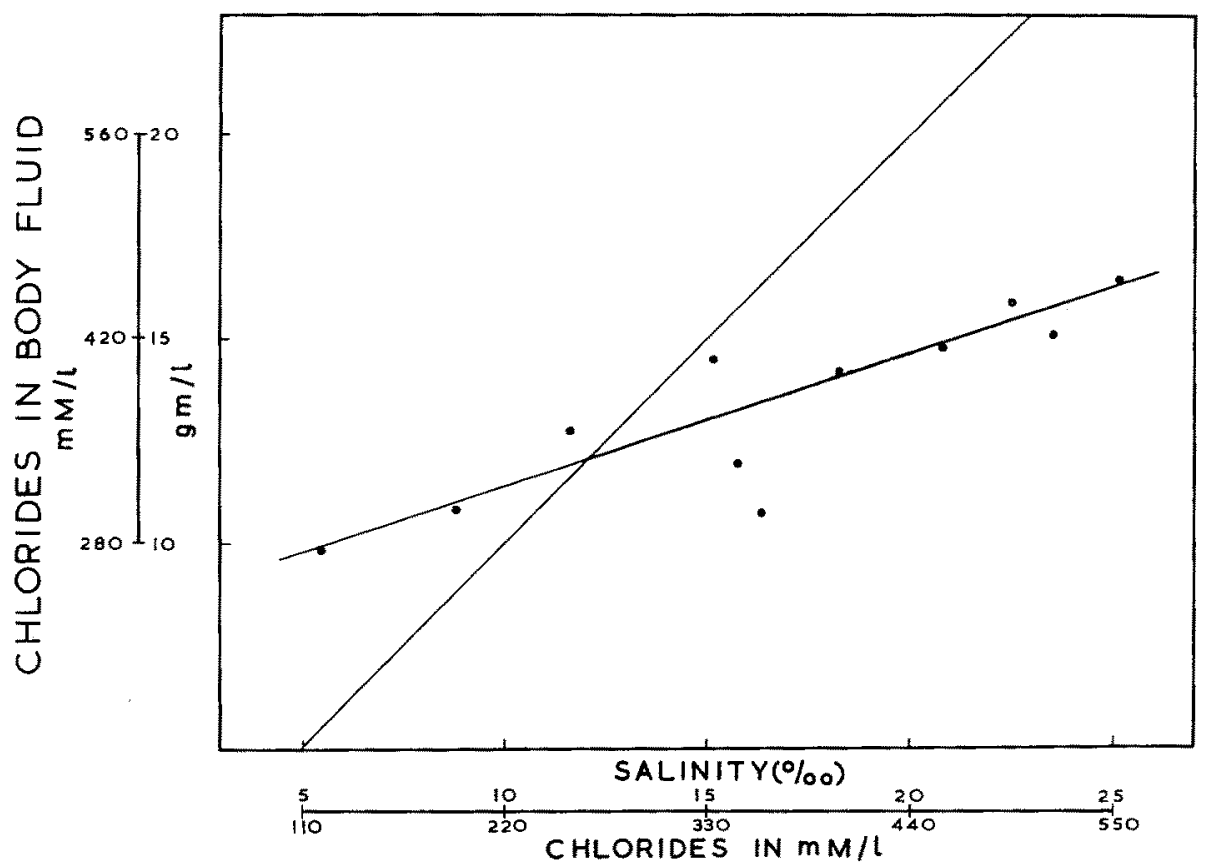

Fig. 1: Relation between the body fluid chlorides of Marphysia gravelyi and external media of varying salinities. Temperature: $25.7 \pm 0.5^{\circ} \mathrm{C}$. Each point is the mean of 3 to 12 estimations. The line running diagonal is the line of isosmocity

on solutions of sodium and potassium salts of known concentrations and similarly diluted up to 200 times, formed the basis of arriving at the concentrations of sodium 
and potassium in the unknown samples of coelomic fluids. The total free amino acids were estimated from $0.1 \mathrm{ml}$ of coelomic fluids made up to $1 \mathrm{ml}$, by the colorimetric method of HARding \& MAclean (1916) in preference to the more elaborate method of Troll \& CANNAN (1953), since it had the additional advantage of being both quick and less cumbersome. Speaking of this method, BLock \& WeIss (1956) comment (p. 29) that "this excellent method has been largely forgotten". The colour intensity dependent upon the amount of free amino acids present was read off on an UNICAM (S. P. 600) Spectrophotometer at $565 \mu$. Standard graphs were prepared with Leucine as suggested by Green \& Stahmann (1955) and Cowgill \& Pardee (1957). In all estimations blanks were run. All reagents were of Analar grade. Controls were run. The procedure of experimentation was similar to that followed in earlier studies in this series (KRISHNAMOOR'THI \& KRISHNASWAMY 1965a, b, c).

The term "body fluid" used in this paper in regard to our results always refers to coelomic fluid. The method of collection of body fluid has been described in an earlier paper (KRISHNAMOORTHI \& KRISHNASWAMY 1965c).

\section{RESULTS}

\section{Regulation of chlorides}

The results of a series of experiments to understand the extent of regulation of chlorides when $M$, gravelyi is exposed to experimental media of varying concentrations

\section{Table 1}

Body fluid chlorides (in $\mathrm{gm} / \mathrm{l}$ and $\mathrm{mM} / 1$ ) of Marpbysa gravelyi after $24 \mathrm{hrs}$ esposure to heterosmotic media. Temperature: $27.5 \pm 0.05^{\circ} \mathrm{C}$

\begin{tabular}{|c|c|c|c|c|c|c|c|}
\hline \multicolumn{2}{|c|}{$\begin{array}{l}\text { Experimental } \\
\text { medium }\end{array}$} & \multicolumn{5}{|c|}{$\begin{array}{c}\text { Chloride values of body fluid after } 24 \mathrm{hrs} \text { of exposurc } \\
\text { to experimental medium }\end{array}$} & \multirow{2}{*}{$\begin{array}{c}\text { Number } \\
\text { of } \\
\text { estimations }\end{array}$} \\
\hline$\% \mathrm{~S}$ & $\begin{array}{c}\text { Chlorides } \\
\text { in } \\
\mathrm{mM} / 1\end{array}$ & $\begin{array}{l}\text { Mean titre } \\
\text { values } \\
\text { in cc }\end{array}$ & $\begin{array}{l}\text { Standard } \\
\text { deviation }\end{array}$ & $\begin{array}{l}\text { Standard } \\
\text { error }\end{array}$ & $\mathrm{mM} / 1$ & $\mathrm{gm} / \mathrm{I}$ & \\
\hline 5.68 & 137 & 0.65 & 0.011 & \pm 0.005 & 272 & 9.64 & 3 \\
\hline 8.52 & 197 & 0.72 & 0.029 & \pm 0.016 & 301 & 10.68 & 3 \\
\hline 10.60 & 256 & 0.86 & 0.011 & \pm 0.004 & 358 & 12.76 & 8 \\
\hline 14.60 & 333 & 0.97 & 0.014 & \pm 0.005 & 406 & 14.39 & 8 \\
\hline 15.30 & 348 & 0.80 & 0.014 & \pm 0.004 & 335 & 11.87 & 12 \\
\hline 16.20 & 358 & 0.73 & 0.017 & \pm 0.006 & 305 & 10.83 & 8 \\
\hline 18.40 & 399 & 0.95 & - & - & 397 & 14.09 & 5 \\
\hline 19.50 & 456 & 1.00 & 0.035 & \pm 0.012 & 418 & 14.84 & 8 \\
\hline 21.60 & 493 & 1.04 & 0.009 & \pm 0.003 & 435 & 15.42 & 12 \\
\hline 23.00 & 517 & 0.95 & 0.012 & \pm 0.003 & 397 & 14.09 & 8 \\
\hline 29.52 & 554 & 1.11 & 0.021 & \pm 0.006 & 464 & 16.46 & 12 \\
\hline
\end{tabular}

are graphically represented in Figure 1 (Table 1). The mean chloride values ranged from $272 \mathrm{mM} / 1(9.64 \mathrm{gm} / \mathrm{l})$ to $464 \mathrm{mM} / \mathrm{l}(16.46 \mathrm{gm} / \mathrm{l})$ in animals exposed to media ranging from $5.68 \%$ to $25.92 \%$ whose chloride values were respectively $137 \mathrm{mM} / \mathrm{l}$ 
and $554 \mathrm{mM} / 1$. The body fluid chlorides are maintained at higher levels of $272 \mathrm{mM} / 1$, $301 \mathrm{mM} / 1$ and $358 \mathrm{mM} / 1$ in the respective external concentrations of $137 \mathrm{mM} / \mathrm{l}$, $197 \mathrm{mM} / 1$ and $256 \mathrm{mM} / \mathrm{l}$.

Although body chloride is still at a high level of $406 \mathrm{mM} / 1$ in a medium of $333 \mathrm{mM} / 1$, it presents a significant deviation from the expected value as can be seen from Figure 1. In the rest of the dilutions from $15.30 \%(348 \mathrm{mM} / 1)$ to $25.93 \%$ $(554 \mathrm{mM} / \mathrm{l})$, the body fluid chloride values ranged from $335 \mathrm{mM} / 1$ to $464 \mathrm{mM} / 1 \mathrm{re}$ spectively. The very low body fluid chloride value of $305 \mathrm{mM} / 1$ in a medium of $16.20 \%(358 \mathrm{mM} / 1)$ represents another significant deviation. These two deviations may have been due to the physiological condition of the worms, although they were looking well when chosen for experimentation (Chi-square tests indicate a probability of $<1 \%$ and thus exclude an experimental artifact). In hyposmotic media the chlorides of the body fluid are kept higher; in hyperosmotic media they are kept lower than in the external medium.

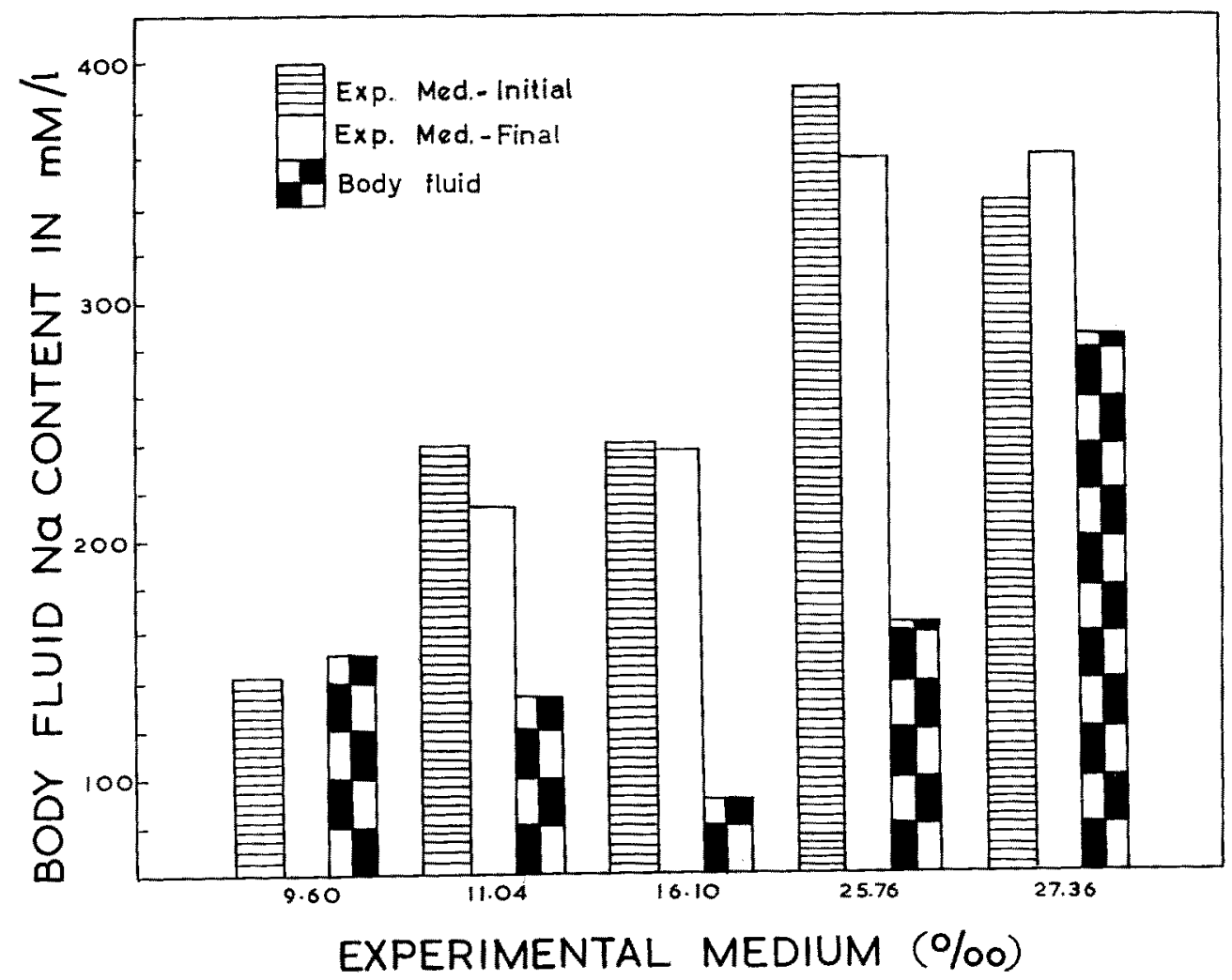

Fig. 2: Sodium levels (mM/l) of body fluids of $M$. gravelyi (mean of 3 to 9 samples) in five different salinities. Temperature: $28.0 \pm 0.5^{\circ} \mathrm{C}$. Exp. Med.: Experimental medium 


\section{Regulation of sodium}

The sodium content of body fluids of worms exposed to 5 different experimental media, namely, $9.60 \%, 11.40 \%, 16.10 \%, 25.76 \%$ and $27.36 \%$, ranged from $90 \mathrm{mM} / 1(16.10 \%$ ) to $285 \mathrm{mM} / 1(27.36 \%)$, as is evident from Figure 2 and Table 2. Sodium content of the external media ranged from $142.5 \mathrm{mM} / 1$ to $362 \mathrm{mM} / \mathrm{l}$ (Fig. 2). The two low values of $90 \mathrm{mM} / 1$ and $135 \mathrm{mM} / 1$ obtained from body fluids of worms subjected to the stresses of external media of $16.10 \%$ and $11.04 \%$, may be attri-

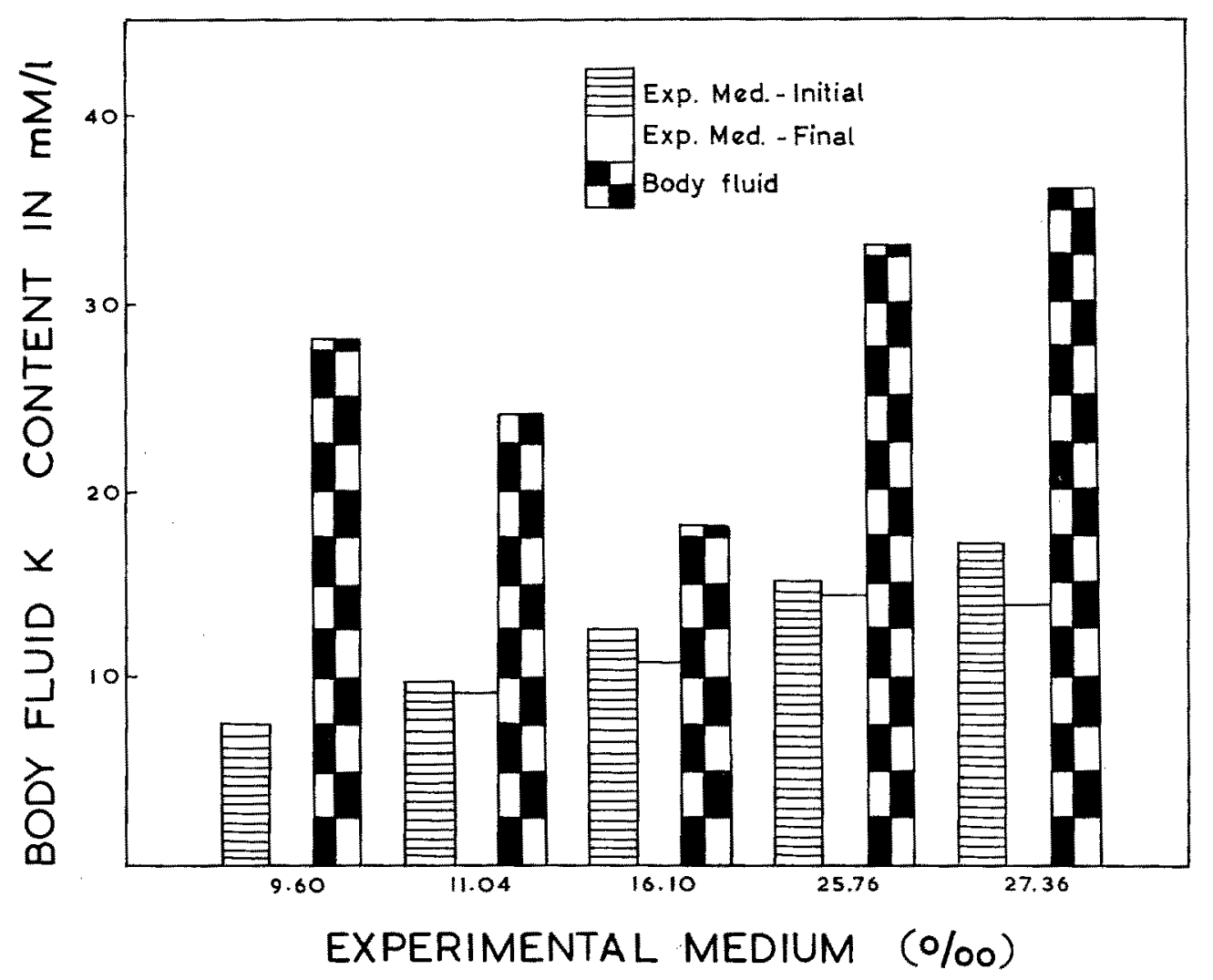

Fig. 3: Potassium levels (mM/1) of body fluids of $M$. gravelyi (mean of 2 to 9 samples) in five different salinities. Temperature: $28.00 \pm 0.5^{\circ} \mathrm{C}$. Exp. Med.: Experimental medium

buted to the physiological condition of the animal prior to its exposure to experimental media (probability $<1 \%$ ). However, that there is an increase in the sodium content with the increase in the concentration of the external medium is evident. Also, except in the lowest dilution when the sodium content of both the body fluids and the external medium are more or less similar, the sodium content of the body fluids in the rest of the experimental media is lower than that of the external medium. This further supports the view that there is active regulation of $\mathrm{Na}$ ions. 


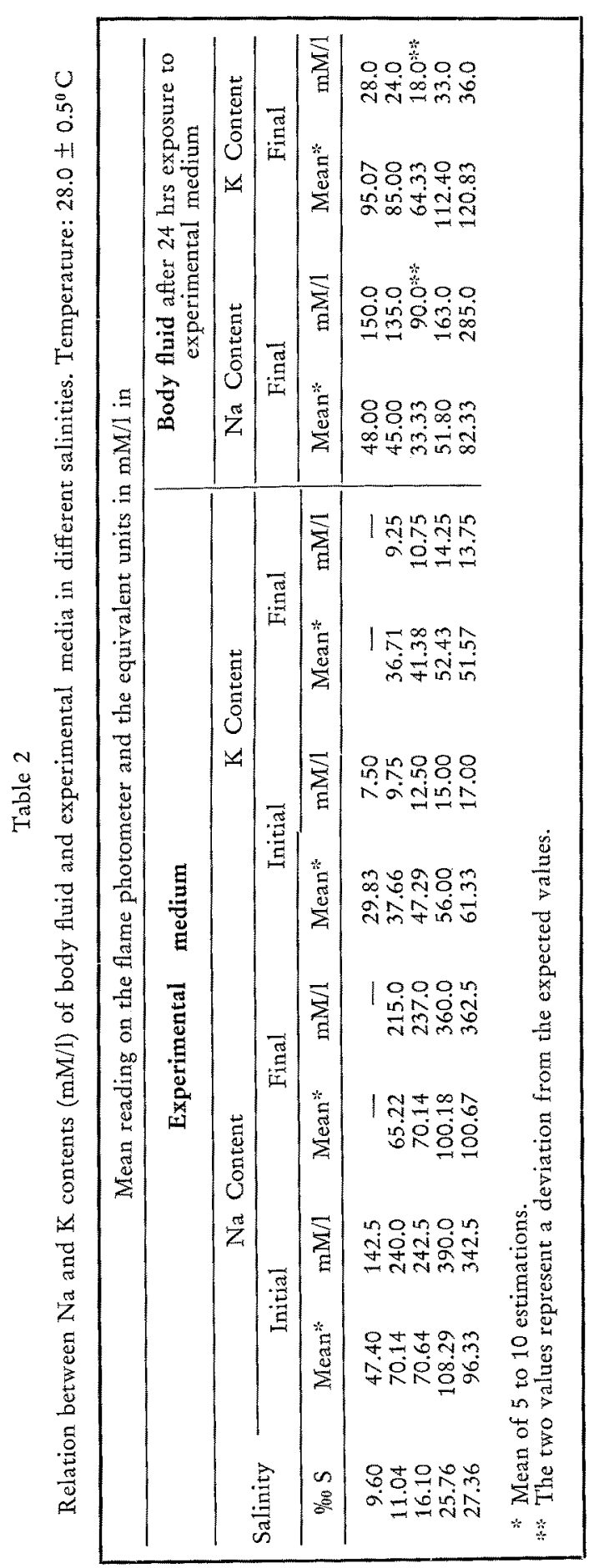




\section{Regulation of potassium}

The potassium content of the body fluids of worms subjected to similar dilutions, as in the previous experiment, ranged from $18 \mathrm{mM} / 1(16.10 \%)$ to $36 \mathrm{mM} / 1(27.36 \%)$ (Table 2). The low value of $18 \mathrm{mM} / \mathrm{l}$ may be due to the same reasons suggested for the low values of sodium, since the same body fluid formed the basis for its estimation. Increase in potassium content of the body fluids with increasing concentrations of external media is similar to that observed for sodium. However, unlike sodium, the potassium content of the body fluids was always higher than those of the experimental media (Fig. 3).

\section{Regulation of total free amino acids}

The total free amino acid content of the body fluid of worms exposed to experimental media of salinities varying from $6.7 \%$ to $29.3 \%$ ranged from $10 \mu \mathrm{g} / \mathrm{ml}$ to $32 \mu \mathrm{g} / \mathrm{ml}$ obtained in the respective dilutions of $6.7 \%$ and $21.6 \%$ (Table 3). A progressive increase in the amino acid content could be seen (Fig. 4) until a dilution of $21.6 \%$ was reached. In dilutions beyond $21.6 \%$, a decline was noticed; perhaps the mechanisms responsible for the increase in lower dilutions break down. In other words, the increase in the amino acid content of the body fluids up to an experimental medium of $21.6 \%$, is a function of osmotic stresses of the media imposed.

Table 3

Total free amino acid levels $(\mu \mathrm{g} / \mathrm{cc})$ in the body fluid of $M$. gravelyi exposed to media of different osmoconcentrations over a period of $24 \mathrm{hrs}$.

Temperature: $29.5 \pm 0.5^{\circ} \mathrm{C}$. Dilution: $1 / 1000$

\begin{tabular}{|c|c|c|c|c|c|}
\hline \multicolumn{2}{|c|}{ Salinity } & \multicolumn{3}{|c|}{ Optical density at $565 \mu$} & \multirow{2}{*}{$\begin{array}{l}\text { Total free } \\
\text { Amino acids } \\
\text { in } \mu \mathrm{g} / \mathrm{cc}\end{array}$} \\
\hline$\% 0 \mathrm{~S}$ & Mean & $\begin{array}{l}\text { Standard } \\
\text { deviation }\end{array}$ & $\begin{array}{l}\text { Standard } \\
\text { error }\end{array}$ & $\begin{array}{c}\text { No. of } \\
\text { estimations }\end{array}$ & \\
\hline 6.7 & 0.083 & 0.023 & \pm 0.091 & 6 & 10 \\
\hline 10.1 & 0.206 & 0.076 & \pm 0.031 & 5 & 18 \\
\hline 15.9 & 0.252 & 0.075 & \pm 0.025 & 10 & 25 \\
\hline 19.4 & 0.302 & 0.019 & \pm 0.008 & 6 & 26 \\
\hline 21.6 & 0.363 & 0.057 & \pm 0.017 & 10 & 32 \\
\hline 25.7 & 0.288 & 0.055 & \pm 0.025 & 5 & 27 \\
\hline 29.2 & 0.177 & 0.046 & \pm 0.018 & 6 & 15 \\
\hline
\end{tabular}

\section{DISCUSSION}

The only polychaete in which chloride regulation has been extensively studied is Nereis diversicolor collected from Millport, Tvärminne, Isefjord and the Upper Tamar Estuary (SMith 1955c). Schlieper (1929a), while giving the depression in the freezing point of $N$. diversicolor from Kiel, has not given the chloride content of its body 


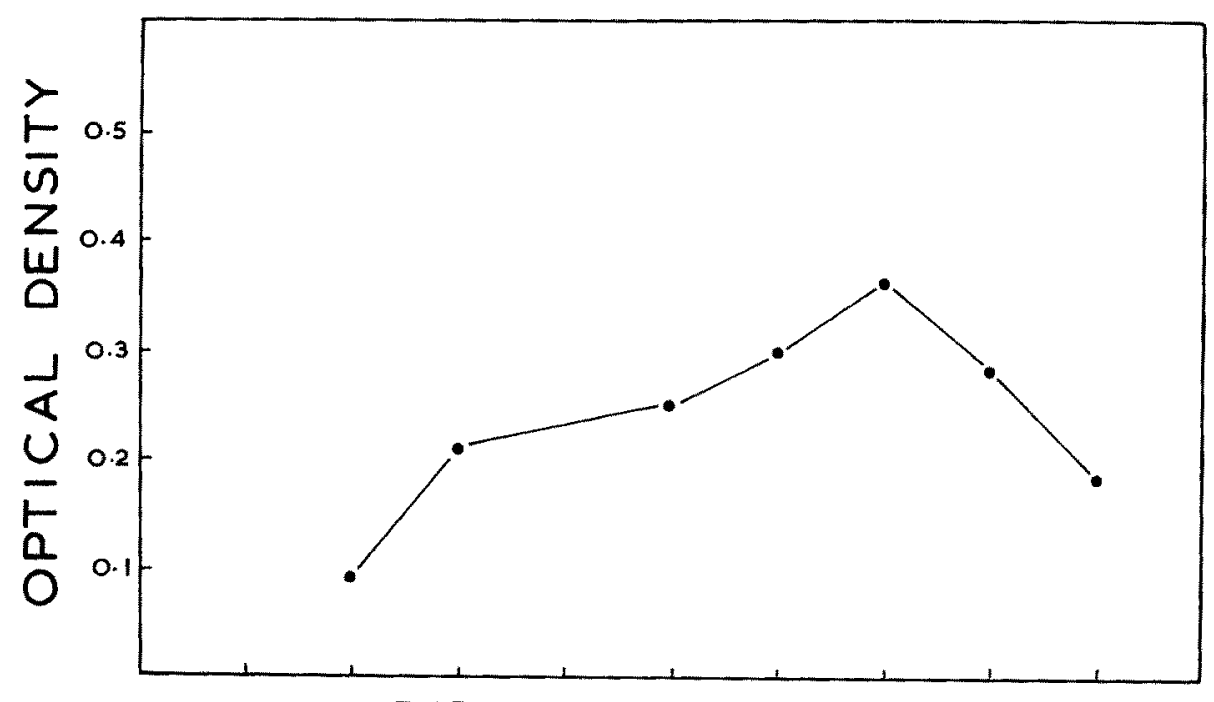

PERCENTAGE SEA WATER

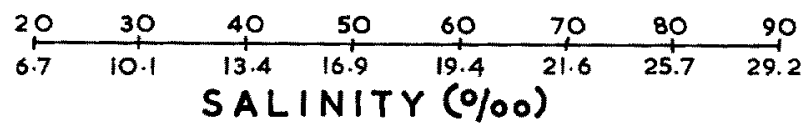

Fig. 4: Relation between total free amino acid levels $(\mu \mathrm{g} / \mathrm{cc}$ ) in body fluids of $M$. gravelyi and concentrations of experimental media. Temperature: $29.5 \pm 0.5^{\circ} \mathrm{C}$. Each point is the mean of 5 to 10 estimations. Each division on the $y$-axis is equal to $10 \mu \mathrm{g} / \mathrm{cc}$

fluid over its range of tolerance of the external medium; however, it could becalculated. The chloride content of $N$. diversicolor thus ranges during its regulatory phase, from $4.80 \mathrm{gm} / 1$ to $19.15 \mathrm{gm} / 1$ at Millport; 3.35 to $9.50 \mathrm{gm} / 1$ at Tvärminne; 3.59 to $8.94 \mathrm{gm} / 1$ at Isefjord; 3.38 to $9.40 \mathrm{gm} / \mathrm{L}$ at the Upper Tamar Estuary and from 7.10 to $18.20 \mathrm{gm} / 1$ at Kiel. In other words, the overall range of chloride content in the body fluid of $N$. diversicolor varied from 3.35 to $19.15 \mathrm{gm} / 1$ over its entire geographical distribution. Nereis limnicola, another nereid polychaete, also has a chloride content ranging from 4.0 to $10.20 \mathrm{gm} / 1$ (SMITH 1959; from his Fig. 12). Since $N$. diversicolor is a hyperregulator, a comparison of chloride values obtained in $N$. diversicolor with that obtained in $M$. gravelyi, being a hypo-regulator and a eunicid, is strictly not tenable. However, the chloride values obtained in $M$. gravelyi, namely, 9.64 to $16.46 \mathrm{gm} / 1$, are rather high and close to chloride values obtained for $N$. diversicolor from $\mathrm{Kiel}$ (SCHLIEPER 1929a). Among four species of nereids, Oglsby (1965) reported a high body fluid chloride content in Nereis limnicola compared with those of $N$. vexilosa, $N$. succinea and Laeonereis culveri and argued that it is, perhaps, due to $N$. limnicola being the "most euryhaline" of the four.

The present investigations have also shown that in $M$. gravelyi the body fluid chloride content is rather high. But the two species $N$. limnicola and $M$. gravelyi are not comparable since the former is a nereid and a hyper-regulator, while the latter is a eunicid and a hypo-regulator. Nevertheless, since both are relatively better regu- 
lators and are most euryhaline, it is conceivable that greater euryhalinity and higher body fluid chloride content are somehow related in pathways or by mechanisms yet unknown, irrespective, of a species, being a hyper- or a hypo-regulator. The stenohaline Pereinereis cultrifera had "slightly less" exchangeble sodium per" gram weight than did the euryhaline $N$. diversicolor (FRETTER 1955). In other words, the more euryhaline a species is, the higher are its body fluid chloride values. The high values of body fluid chlorides in $M$. gravelyi could therefore represent a consequence of its euryhalinity.

SMTTH (1955c), without making parallel determinations of the depression in the freezing point and the corresponding chloride content of the body fluid of $N$. diversicolor during its regulatory phase, suspected that the chloride concentration may not parallel the osmotic pressure of the coelomic fluid, especially at low salinities. Comparing the osmotic pressure of the body fluids obtained in $M$. gravelyi (compare Figs. 1 and 5) with the chloride values, the conclusion that they parallel each other appears reasonable.

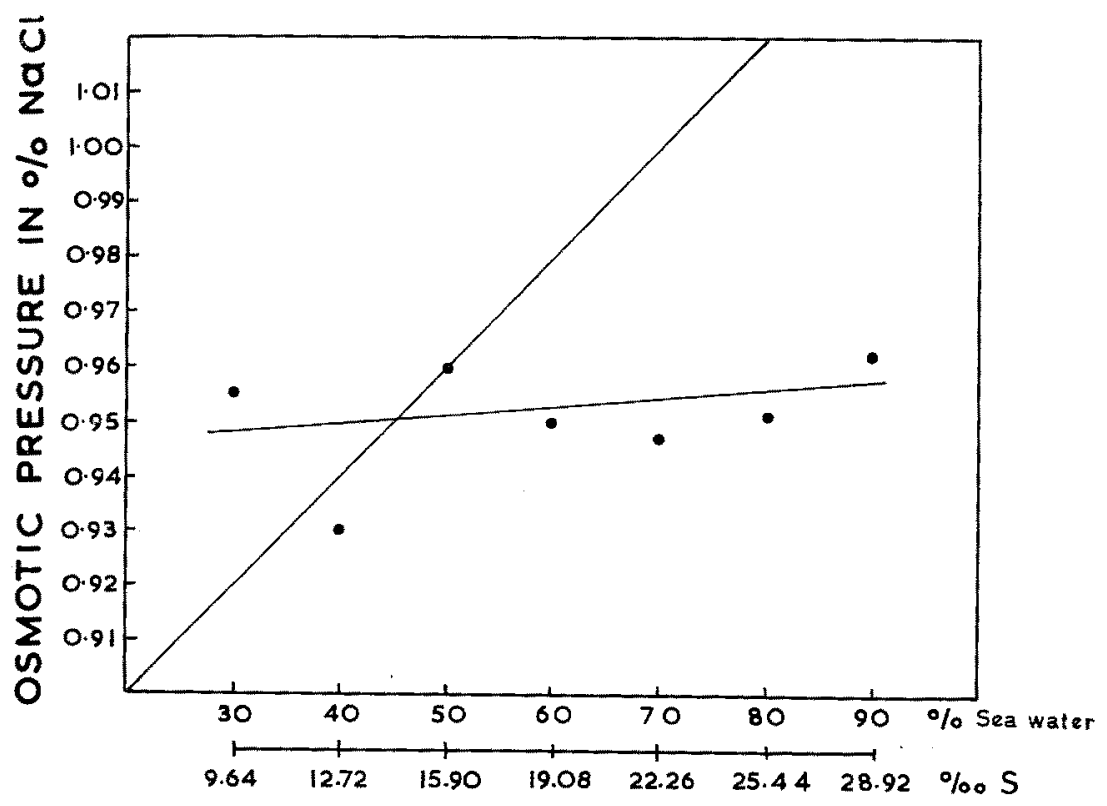

EXPERIMENTAL MEDIUM

Fig. 5: Osmotic pressure of body fluids of $M$. gravelyi in terms of $\% \mathrm{NaCl}$ after $24 \mathrm{hrs}$ exposure to heterosmotic media. Temperature: $28.0^{\circ} \pm 0.5^{\circ} \mathrm{C}$. Each point is the mean of 5 estimations. The diagonal line is the line of isosmocity. Taken from KRISHNAMOorTHI \& KRISHNAsWAMY (1965c)

Studies on ionic regulation in polychaetes attempting to invade regions other than they are normally accustomed to, were largely neglected although its importance was realized. An attempt in this direction was made very early by SCHLIEPER (1929a) in Arenicola marina and later by BetHe \& Berger (1931) and Bialaszewicz (1933) in 
Arenicola sp., Amphitrite sp., and Apbrodite sp, and was closely followed by ConE (1940) in some more genera of polychaetes. However, they provided only a catalogue of the inorganic constituents of the body fluids of the animals. The credit for giving an impetus to this aspect goes to WEBb's thought provoking paper (1940) on Carcinus maenas.

In a series of papers ROBERTSON $(1949,1953,1957,1960$ a) brought to light not only the existence of ionic regulation among lower invertebrates but also interspecific differences. The results presented here are not strictly comparable with those obtained by RoBertson $(1949,1953)$ because the methods employed differ from each other. While Robertson $(1949,1953)$ estimated the inorganic constituents of the body fluids both before and after dialysis, in the present investigations chemical analyses of the body fluids obtained as such after exposure to experimental media were made without dialysis. However, it was seen that the ions studied - Cl, Na and $\mathrm{K}-$ increased with increasing concentration of the external medium. The accumulation of $\mathrm{K}$ needs no further explanation, since it is of common occurrence (RoBertson 1949, 1953, PARRY $1953,1954)$. Whether or not the increase of $\mathrm{Na}$ and $\mathrm{Cl}$ is also a case of accumulation, may perhaps be decided on the basis of dialysing experiments as suggested by RoBERTSON (1949).

Table 4

Values and ratios of body fluid ion concentrations (mM/1) in M. gravelyi. Figures in brackets represent values of the respective ions in the external media

\begin{tabular}{|ccccccccc|}
\hline Salinity & \multicolumn{3}{c|}{ Values } \\
\cline { 2 - 6 }$\%$ & $\mathrm{Cl}$ & $\mathrm{Na}$ & $\mathrm{K}$ & $\mathrm{Na}: \mathrm{Cl}$ & $\mathrm{K}: \mathrm{Cl}$ & $\mathrm{K}: \mathrm{Na}$ & $(\mathrm{Na}+\mathrm{Cl}):(\mathrm{K}+\mathrm{Cl})$ \\
\hline 9.60 & 301 & 150 & 28 & & & & \\
& $(197)$ & $(142.5)$ & $(7.50)$ & $1: 2$ & $1: 11$ & $1: 5$ & $1: 1.4$ \\
11.04 & 358 & 135 & 24 & $1: 3$ & $1: 15$ & $1: 5$ & $1: 1.3$ \\
& $(256)$ & $(215)$ & $(9.75)$ & & & & \\
16.10 & 305 & 90 & 18 & & & & \\
& $(358)$ & $(237.5)$ & $(12.5)$ & $1: 3$ & $1: 17$ & $1: 5$ & $1: 1.2$ \\
& 464 & 163 & 33 & & & & $1: 1.2$ \\
25.76 & $(554)$ & $(360)$ & $(15)$ & $1: 3$ & $1: 14$ & $1: 5$ & 1.5 \\
\hline
\end{tabular}

Ion ratios (Table 4) indicate that all ions are regulated. The $\mathrm{Cl}$ values ranged from $301 \mathrm{mM} / 1$ to $464 \mathrm{mM} / 1$ and the $\mathrm{Na}$ values from $90 \mathrm{mM} / 1$ to $163 \mathrm{mM} / 1$ in the four experimental media chosen; yet when the ratios of $\mathrm{Cl}: \mathrm{Na}$ are considered, it will be seen that these are maintained at $1: 3$. Similarly the ratios between $\mathrm{K}: \mathrm{Cl}$ are maintained at $1: 11$ to $1: 17$ and the ratio between $\mathrm{K}: \mathrm{Na}$ is remarkably consistent at $1: 5$. Even when they are considered together, it is seen that the ratio between $(\mathrm{Na}+\mathrm{Cl}):(\mathrm{K}+\mathrm{Cl})$ is maintained at a fairly constant figure. In the light of these results, the observation of ROBERTSON $(1949,1953)$ - that only in decapod crustaceans an accumulation of $\mathrm{K}$ and $\mathrm{Na}$ could be possible - cannot be supported. An accumulation of $\mathrm{Na}$ is perhaps not possible in Arenicola marina (studied by RoBERTSON 1949), which is a purely marine species and which shows toleration of reduced salinities over a relatively narrower range. Arenicola marina seems not a good choice to 
establish the generalisation that regulation of $\mathrm{Na}, \mathrm{K}$ and $\mathrm{Cl}$ is restricted to Crustacea and Cephalopoda and that polychaetes lack this ability; in $M$. gravelyi regulation extends to all the three ions studied. The mechanism(s) responsible for this regulation is (are) obscure. Perhaps, the excretory organs play an important part. When $A$. marina, which maintains its body fluid isosmotic to an external medium of $44 \%$ sea water (SCHLIEPER 1929a), were exposed to dilutions, equilibrium with the surrounding medium was soon established except in the case of $\mathrm{K}$ and $\mathrm{SO}_{4}$ (ROBERTSON 1949). ROBERT'SON presumed that this may be a consequence of the selective activity of the nephromixia and the control of the absorption of these ions by the body wall. Since the ratio of the excretory surface to the length of the worm is greater in $M$. gravelyi than those of other polychaetes that coexist with $M$. gravelyi (KRISHNAMOORTHI 1963a; Krishnamoorthi \& Krishnaswamy 1965d), as reported (size) in $N$. diversicolor (JüRGENS 1935) and in Lycastis indica (KRISHNAN 1952), it is conceivable that nephridia do play a part as suspected by Grobben (1881), Krishnan (1952) and Jørgensen \& Dales (1957) in annelids, and argued by Schwabe (1933), Peters (1935) and Hynes (1954) in crustaceans, who associated excretion of hyposmotic urine with the size and structure of nephridia. But until more refined techniques for the collection of urine in polychaetes are developed, the extent of the role played by nephridia in the conservation of these salts must remain a matter of speculation. Furthermore, it is possible that sodium/chloride in $M$. gravelyi is being taken up and (or) eliminated by well developed branchiae situated along the whole length of the worm (AIYAR 1933).

Since chlorides are the major ions in the body fluids of animals (RoBERTSON 1953 ), it may be assumed that they contribute by a major part to the osmotic pressure. It was seen earlier that the chloride values parallel fairly well the depression in the freezing point of the body fluid in $M$. gravelyi. However, even this ion does not make up all the osmotic pressure of the external medium, especially when exposed to media of higher concentrations. Perhaps, it does in the lower dilutions (Fig. 1). Recent work indicates that the organic constituents like the amino acids (BRICTEUX-GregorRe et al. 1961, Duchateau-Bosson et al. 1961, Duchateau-Bosson \& Florkin 1961) and the glycogen (Wilber 1948, WILBer \& MACDonatd 1950) also help to adjust the osmotic pressure. The results presented here on the regulation of the total free amino acids in $M$. gravelyi appear to support this view since the progressive increase of amino acid content with increasing concentration up to a point, suggests such a possibility. Jeuniaux et al. (1961) and Duchateau-Bosson \& Florkin (1961) have shown that such an adjustment in Arenicola marina and Perinereis cultrifera - although present is not as well developed as in the more euryhaline Nereis diversicolor which osmoregulated better than the two previously mentioned polychaetes. In other words, in $M$. gravelyi there is not only osmoregulation of the body fluid but also intracellular adjustment, realized, at least partly, by marked changes of the concentration of intracellular free amino acids.

Preliminary results obtained by chromatographic separation of amino acids of body fluids (unpublished data) have shown that $M$. gravelyi may be regulating glycine, similar to the situation reported in Arenicola marina (Duchateau-Bosson et al. 1961) and Perinereis cultrifera and Nereis diversicolor (Jeuniaux et al. 1961). 


\section{SUMMARY}

1. Regulation in $M$. gravelyi is extended to all ions, namely, chlorides, sodium and potassium.

2. The ratios between $\mathrm{Na}$ to $\mathrm{Cl}, \mathrm{K}$ to $\mathrm{Cl}, \mathrm{K}$ to $\mathrm{Na}$, and $(\mathrm{Na}+\mathrm{Cl})$ to $(\mathrm{K}+\mathrm{Cl})$ are held remarkably constant.

3. In addition to osmocentration of the body fluids, $M$. gravelyi also resorts to intracellular regulation in which amino acids, at least partly, are involved.

\section{A.CKNOWLEDGEMENTS}

The authors are greatly indebted to Dr. O. KinNe, Leading Director and Professor, Biologische Anstalt Helgoland, for offering valuable criticism and improving our manuscript. One of the authors (B.K.) wishes to express his grateful thanks to Dr. K. PAMpapathr RaO, Professor of the Department of Zoology, Sri Venkateswara University, Thirupathi, for providing him with facilities at the Thirupati Laboratories. He wishes also to thank Drs. R. RamaMURhti and $K$. Padmanabha Naddu for assisting him in the estimation of sodium and potassium.

\section{LITERATURE CITED}

Aryar, R. G., 1933. On the anatomy of Marphysia gravelyi Southern. Rec. Indian Mus. 35, $287-323$.

Beadle, L. C., 1957. Comparative physiology: Osmotic and ionic regulation in aquatic animals. A. Rev. Physiol. 19, 329-358.

Bethe, A. \& Berger, E., 1931. Variationen im Mineralbestand verschiedener Blutarten. Pfliigers Arch. ges. Physiol. 227, 571-584.

Bralasze wicz, K., 1933. Contribution a l'étude de la composition minerale des liquides nourriciers chez les animaux marins. Archs int. Physiol. 36, 41-53.

Brock, R. J. \& WeIss, K. W., 1956. Amino acid handbook. Methods and results of protein analysis. C. C. Thomas, Springfield, Ill., 386 pp.

BricteuX-Gregoire, S., Jeuniaux, Ch. \& Florkin, M., 1961. Rôle de la variation de la composante amino-acide intracellulaire dans l'euryhalinite de Leander serrams F., et de Leander squilla L. Archs int. Physiol. 69, 744-745.

Bryan, G. W., 1960a. Sodium regulation in the cray fish, Astacus fuviatilis. 1. The normal animal. J. exp. Biol. 37, 83-99.

- 1960b. Sodium regulation ...2. Experiments with sodium depleted animals. J. exp. Biol. 37, 100-112.

- 1960c: Sodium regulation ... 3. Experiments with NaCl-loaded animals. J. exp. Biol. 37, $113-128$.

Cone, H. W., 1940. The composition of fluids and sera of some marine animals and of the sea water in which they live. J. gen. Physiol. 23, 575-584.

Cowgrll, R, W. \& PARDEE, A. B., 1957. Experiments in biochemical research techniques. Wiley \& Sons, New York; Chapman \& Hall, London, 189 pp.

Duchateau-Bosson, Gr. \& Florkin, M., 1961. Change in intracellular concentration of free amino acids as a factor of euryhalinity in the cray fish, Astacus astacus. Comp. Biochem. Pbysiol. 3, 245-250.

-, Jeuniaux, C. \& Florkin, M., 1961. Rôle de la variation de la composante amino-acide intracellulaire dans l'euryhalinité d'Arenicola marina L. Archs int. Physiol. 69, 30-35.

FRETTER, V., 1955. Uptake of radioactive sodium ( $\left.{ }^{24} \mathrm{Na}\right)$ by Nereis diversicolor Mueller and Perinereis cultrifera (Grube). J. mar. biol. Ass. U. K. 34, 151-160. 
Green, M. \& Stahmann, M. R., 1955. Preparation and enzymatic hydrolysis of poly-x-ethylglutamyl bovine plasma albumin. J. biol. Chem. 213, 259-269.

Grobben, C., 1881. Die Antennendrüse der Crustaceen. Arb. zool. Inst. Univ. Wien 3, 93-110.

Harding, V. J. \& Maclean, R. M., 1916. A colorimetric method for the estimation of aminoacid a-nitrogen. 2. Application to the hydrolysis of proteins by pancreatic enzymes. J. biol. Chem. 24, 503-517.

Hynes, H. B. N., 1954. The ecology of Gammarus duebeni Lilleborg and its occurrence in fresh water in Western Britain. J. Anim. Ecol. 23, 38-84.

Jeuniaux, Ch., Duchateau-Bosson, Gh. \& Florkin, M., 1961. Free amino acids in the intracellular osmoregulation of euryhaline marine worms. Biochem. J. 79, 24-25.

-, - , - 1961. Variation de la composante amino-acide des tissues et euryhalinité chez Perinereis cultrifera Gr. et Nereis diversicolor (O. F. Muller). J. Biochem., Tokyo 49, 527-531.

Jorgensen, C. B. \& Dales, R. P., 1957. The regulation of volume and osmotic regulation in some nereid polychaetes. Physiologia comp. Oecol. 4, 357-374.

Jürgens, O., 1935. Die Wechselbeziehungen von Blutkreislauf, Atmung und Osmoregulation bei Polychaeten (Nereis diversicolor O. F. Muller). Zool. Jb. (Allg. Zool. Physiol.) 55, 1-46.

Krishnan, G., 1952. On the nephridia of Nereidae in relation to habitat. Proc, natn. Inst. Sci. India 18, 241-245.

KrishNamoorthi, B., 1962. Salinity tolerance and volume regulation in four species of polychaetes. Proc. Indian Acad. Sci. 56, 363-371.

- 1963a. Gross morphology and histology of nephridia in four species of polychaetes. Proc. Indian Acad. Sci. 57, 195-209.

- 1963c. Chloride regulation in Marpbysa gravelyi Southern. Curr. Sci. 32, 463-464.

- \& Krishnaswamy, S., 1963. Activity of Marpbysa gravelyi Southern (Polydaeta) under heterosmotic conditions. Proc. Indian Acad. Sci. 57, 83-87.

-, - 1965a. Physiological studies on Marphysa gravelyi Southern. 1. Salinity tolerance. Proc. Indian Acad. Sci. (in press).

-, - 1965b. Physiological studies ... 2. Volume regulation. Proc. Indian Acad. Sci. (in press).

-, - 1965c. Physiological studies... 3. Regulation of body fluid concentration. Zool. Jb. (allgem. Zool. Physiol.) (in press).

-, - 1965d. Physiological studies ... 4. Structure of Nephridia (unpublished).

-, - 1965f. Ionic regulation in Marphysa gravelyi Southern. Curr. sci. (in press).

OGLSBY, L. C., 1965. Steady-state parameters of water and chloride regulation in estuarine nereid polychaetes. Comp. Biochem. Physiol. 14, 621-640.

Pantin, C. F. A., 1931. The origin of the composition of the body fluids of animals. Biol, Rev. 6, 459-482.

ParrY, G., 1953. Osmotic and ionic regulation in the isopod crustacean, Ligia oceanica. J. exp. Biol. 30, 567-574.

- 1954. Ionic regulation in the palaemonid prawn, Palaemon (=Leander) serratus. J. exp. Biol. 31, 601-613.

Peters, H., 1935. Ober den Einfluß des Salzgehaltes im Außenmedium auf den Bau und die Funktion der Exkretionsorgane Dekapoder Crustaceen. (Nach Untersuchungen an Potamobius fuviatilis und Homarus vulgaris.) Z. Morpb. Ökol. Tiere 30, 355-381.

Robertson, J. D., 1939. The inorganic composition of the body fluids of three marine invertebrates. J. exp. Biol. 16, 387-397.

- 1949. Ionic regulation in some marine invertebrates. J. exp. Biol. 26, 182-200.

- 1953. Further studies on ionic regulation in marine invertebrates. J. exp. biol. 30, 277-296.

- 1957. Osmotic and ionic regulation in aquatic invertebrates. In: Recent advances in invertebrate physiology. Ed. by B. T. Scheer. Univ. of Oregon, Eugene, Oreg., 304 pp.

- 1960a. Osmotic and ionic regulation. In: The physiology of crustacea. Ed. by T. H. Waterman. Acad. pr., New York, Vol. 1, 317-339.

- \& WEBB, D. A., 1939. The micro-estimation of sodium, potassium, calcium, magnesium, chloride and sulphate in sea water and the body fluids of marine animals. J. exp. Biol. 16, 155-177. 
SCHLIEPER, C., 1929a. Ubet die Einwirkung niederer Salzkonzentration auf marine Organismen. Z. vergl. Physiol. 9, 478-514.

SchWabE, E., 1933. Über die Osmoregulation verschiedener Krebse (Malacostraceen). Z. vergl. Physiol. 19, 183-235.

SENDROY, J., 1937. Microdetermination of chloride in biological fluids with solid silver iodate. J. Biol. Chem. 120, 305-403.

SHAw, J., 1955a. Ionic regulation and water balance in the aquatic larva of Sialis lutaria. J. exp. Biol. 32, 353-382.

- 1955b. The permeability and structure of the cuticle of the aquatic larva of Sialis lutaria. J. exp. Biol. 32, 330-352.

- 1960c. The mechanisms of osmoregulation. In: Comparative biochemistry. Ed. by. M. Florkin \& H. S. Mason. Acad. Pr., New York, Vol. 2, 471-518.

- 1960c. The absorption of chloride ions by the cray-fish, Astacus pallipes Lereboullet. J. exp. Biol. 37, 557-572.

Smrth, R. I., 1955c. Comparison of the level of chloride regulation by Nereis diversicolor in different parts of its geographical range. Biol. Bull. mar. biol. Lab., Woods Hole 109, 453-474.

- 1959. Physiological and ecological problems of brackish-waters. In: Marine biology. Proceedings of the 20th Annual Biology Colloquium, Oregon State College, April 1959, 59-69.

TRoll, W. \& CanNan, R. K., 1953. A modified photometric ninhydrine method for the analysis of amino and imino acids. J. biol. Chem. 200, 803-811.

WEBB, D. A., 1940. Ionic regulation in Carcinus maenas. Proc. R. Soc. (B) 129, 107-136.

Wells, G. P. \& Ledingham, I. C., 1940a. Physiological effects of a hypotonic environment. 1. The action of hypotonic salines on isolated rhythmic preparations from polychaete worms (Arenicola marina, Nereis diversicolor, Perinereis cultrifera). J. exp. Biol. 17, $337-352$

WrLber, C. G., 1948. Glucose content of the body fluid in marine annelids. J. biol. Chem. 173, 141-143.

- \& McDonald, E. S., 1950. Glucose metabolism in marine worms. J. scient. Soc. Harcourt Butler technol. Inst. 1, 7-11. 